\title{
The Effect Of Health Education On Blood Pressure Behavior Behavior In Hypertension Patients
}

\author{
Hamdana 1, A.Nurlaela Amin'², Misra ${ }^{3}$ \\ S1 Nursing Study Program, Stikes Panrita Husada Bulukumba, Indonesia ${ }^{1}$ \\ Departemen Community and Family Nursing , Stikes Panrita Husada Bulukumba, Indonesia ${ }^{2}$ \\ Departemen Surgical and Medical Nursing, Stikes Panrita Husada Bulukumba ,Indonesia ${ }^{3}$
}

\section{Corresponding Autor : Alleaalle@gmail.com*}

\begin{abstract}
Based on the amount of data obtained from Bonto Bangun health center where in 2015 there were only 305 people suffering from hypertension, in 2016 there were 236 people, and in 2017 there was an increase in hypertension, namely 356 people and in 2018 for 3 months there were 70 people suffering from hypertension. The purpose of this study is to know the effect of health education on blood pressure reduction behavior in hypertensive patients in the work area of Puskesmas Bonto Bangun Kec, Rilau Ale, Bulukumba District. This type of research is a preexperimental study with a pre-experimental approach: one group pretest-posttest design. With simple random sampling data collection techniques with the number of samples in this study as many as 36 respondents through questionnaire sheets. Data analysis using paired t test with significance level $\alpha=0.05$. The results of data analysis showed that the behavioral variable $p=$ 0,000 , it can be concluded that there is an effect of health education on blood pressure reduction behavior in hypertensive patients in the work area of Puskesmas Bonto wake. Conclusion there is the influence of health education on blood pressure reduction behavior in hypertensive patients. Suggestions are expected to be given health education through regular counseling or other media by relevant agencies especially regarding hypertension
\end{abstract}

Keywords: Health Education, Blood Pressure, Reduction Behavior

\section{INTRODUCTION}

Hypertension is a condition where the increase in blood pressure exceeds the normal limit and the most optimal is $120 \mathrm{mmHg}$ for systolic and $80 \mathrm{mmHg}$ for diastolic. Hypertension that occurs in a long time continuously can usually cause a stroke, heart attack, pulmonary edema, blindness, and hearing decline. There are several risk factors for hypertension, such as an increase in age or a history of blood pressure in family members (Runtukahu, Rompas, \& Pondaag, 2015). According to WHO (World Health Organization 2012), there are a total of 839 million cases of hypertension, and it is estimated that the prevalence of hypertension will increase in 2025 to 1.15 billion or around $29 \%$ of the total world population where women suffer $30 \%$ more than the sufferer's men $29 \%$. About $80 \%$ of cases of hypertension will increase, especially in developing countries (Runtukahu, Rompas, \& Pondaag, 2015). 


\section{COMPRABHENSWE HAHW CARE}

Data obtained from the Bulukumba district health office regarding hypertension in 2016 showed that 10,430 were suffering from hypertension, with 3,828 men suffering from women and 6,602 women (Health Office 2016). Data from the Bonto Bangun Health Center on hypertension data recorded in 2015 there were 305 people suffering from hypertension, in 2016 there were 238 people, and in 2017 and increase in hypertension was 356 people and in 2018 for 3 months there were 70 people who suffered from hypertension. Various studies have proven that hypertension prevention measures among the public. The results of this study were previously conducted by Ainal Mardiah, Asnawi Abdullah, Hermansyah in 2016 with the title "Health Education in Increasing Knowledge and Family Skills with Hypertension. The purpose of this study was to analyze whether there is an influence of health education on the behavior of reducing blood pressure in hypertensive patients in the work area of the Rilau Ale, Bulukumba Regency.

\section{MATERIAL AND METHODS}

The design of this study is a pre-experimental study with a pre-experimental approach: one group pretest-posttest design, which aims to determine the effect of health education on the behavior of reducing blood pressure in hypertensive patients in the Bonto Bangun Puskesmas Puskesmas, Rilau Kab, Bulukumba. Population is a generalization area consisting of objects/subjects that have certain qualities and characteristics determined by researchers to be studied and then drawn conclusions (Sugiyono, 2012).

The population in this study were all hypertension sufferers who came for treatment at the Bonto Bangun Health Center Work Area with a total of 70 people for 3 months in 2018. Sampling in this study uses nonprobability sampling with a purposive sampling method that is the technique of determining samples with certain considerations (Setiadi, 2013). The sample in this study were 36 people who suffered from hypertension. Based on the sampling formula according to Isaac and Michael.

In the variable of health education using counseling material about hypertension, the tools used are lefleat and brochure. On the blood pressure-lowering behavior variable using a Likert scale questionnaire consisting of 11 statement items with frequent answer choices (s) score 4, always (s) score 3 sometimes (k) score 2, never (tp) score 1. The research instrument (questionnaire) must meet the requirements of valid and reliable. Data were analyzed based on measuring scale and research objectives 


\section{COMPRABHENSWE HEAH CARE}

using computerized program software. Data were analyzed by: (1). Univariate Analysis, Analysis is done to see the proportion. (2). Bivariate Analysis, Bivariate test was conducted to determine the effect of the independent and dependent variables with the test used was the paired t-test. and the accepted significance limit if $\mathrm{p}<0.05$.

\section{RESULTS}

Table 1. Distribution of Respondent Characteristics by Gender, Age, Last Education

\begin{tabular}{|c|c|c|}
\hline Characteristics & $\mathrm{n}$ & Percentage (\%) \\
\hline \multicolumn{3}{|l|}{ Gender } \\
\hline Male & 5 & 1,9 \\
\hline Female & 31 & 86,1 \\
\hline \multicolumn{3}{|l|}{ Age } \\
\hline Late adulthood & 4 & 11,1 \\
\hline Early Elderly & 14 & 38,9 \\
\hline Late Elderly & 8 & 22,2 \\
\hline Old man & 10 & 27,8 \\
\hline \multicolumn{3}{|l|}{ Last education } \\
\hline Elementary school & 27 & 75,0 \\
\hline Middle School & 6 & 16,7 \\
\hline High school & 3 & 8,3 \\
\hline Amount & 36 & 100,0 \\
\hline
\end{tabular}

Based on table 1 the frequency distribution of the characteristics of respondents was 36 respondents with a female gender more than 31 people (86.1\%), compared to the male gender of 5 people (1.9\%). Whereas the distribution based on the criteria for the age of the beginning of the elderly was 14 more people (38.9\%), compared to the criteria for the age of the late adult as much as 4 people (11.1\%). Based on educational background, namely elementary school education more 27 people (75.0\%) compared to high school education of 3 people (8.3\%).

Table 2. Distribution of the Frequency of Hypertension Patient Behavior in the Working Areas of the Bonto Public Health Center before and after health education is given

\begin{tabular}{ccccc}
\hline Behavior & \multicolumn{2}{c}{ Pre } & \multicolumn{3}{c}{ Post } \\
\cline { 2 - 5 } & $\mathbf{n}$ & $\%$ & $\mathbf{n}$ & $\mathbf{2}$ \\
\hline Good & 10 & 27,8 & 28 & 77,8 \\
Not Good & 26 & 72,2 & 8 & 22,2 \\
\hline Amount & 36 & $\mathbf{1 0 0 , 0}$ & 36 & $\mathbf{1 0 0 , 0}$ \\
\hline
\end{tabular}

Based on table 5.2 it is found that behavior in hypertensive patients before being given health education is not good behavior more than 26 people (72.2\%), compared with good behavior as many as 10 people (27.8\%). After being given health behavioral education in hypertensive patients, 28 people (77.8) had good behavior compared to 8 people (22.2). 
Tabel 3. Analysis of the Effects of Health Education on Behavior in Decreased TD

\begin{tabular}{lllllllll}
\hline & \multicolumn{3}{c}{ Paired Differences } & \multicolumn{3}{c}{ P Value } \\
\cline { 2 - 8 } & \multicolumn{2}{c}{$95 \%$ Confidence Interval of the Difference } & & & \\
\cline { 2 - 8 } & Mean & Std. De & Lower & Upper & t & df & \\
\hline $\begin{array}{l}\text { Decline_TD_Pre and Post } \\
\text { behavior }\end{array}$ & 0.500 & 0.507 & 0.328 & 0.672 & 5.916 & 35 & \\
\hline
\end{tabular}

Based on table 3 it was found that the behavior of hypertensive patients after being given health education to the behavior of BP pre-behaviors decreased by 26 people (72.2\%) and those who behaved well as many as 10 people (27.8\%). Whereas the decrease in post BP behavior that behaved unfavorably was 8 people (22.2\%) and well behaved 28 people (77.8\%). Based on paired t test results obtained p value $<0,000$ with a significant level value $<0.005$ so it can be concluded that there is an influence of health education before and after health education on the behavior of BP reduction in hypertensive patients in the work area of Bonto Wake Health Center.

\section{DISCUSSION}

Lifestyle behavior is a risk factor that influences the incidence of hypertension because it is influenced by unhealthy lifestyles, modern lifestyles tend to reduce physical activity (exercise), alcohol consumption, drinking coffee, smoking and prolonged stress. All of these behaviors are triggers for high blood pressure. This research had previously been conducted by Rendi, Tavip Dwi Wahyuni, Warsono with the title "The Effect of Health Education About Hypertension on Changes in Lifestyle Behavior of Clients in Health Centers in Malang District" in 2017. The sample in this study was 20 respondents who were known before being given behavioral health education is more than 18 people (90\%) compared with less behavior (2\% (10\%)).

Whereas research conducted by Riana D. Jurwari, Hendro Badjuni, Abram Babakal with the title "The Effect of Health Education on Knowledge of Hypertension Client Behavior in Manado Shoulder Health Center" in 2014. The sample in this study was 59 respondents, before being given health education less good behavior more 33 people (56\%), compared with 26 good people (44\%). The researchers' assumptions are related to the study that the behavior of hypertensive patients before the provision of health education, was found to be less good behavior 26 people (72.2\%), compared with good behavior as many as 10 people (27.8\%) where hypertension pesien seldom do sports, do not avoid eating restrictions that cause increased blood pressure, and do not limit 


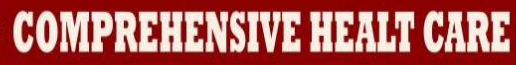

foods that contain high salt. Because of the lack of information they get related to health problems.

After being given health education behavior in hypertensive patients changed were 28 people (77.8\%) good behavior, compared to 8 people (22.2\%) less good behavior.

Based on table 5.3 the results of the analysis using a paired t-test with a significant level ( $\alpha=0.05)$ based on the test results obtained $p$-value $<\alpha(0,000<0.005)$ so it can be concluded that there is an effect of health education on the behavior of reducing blood pressure in hypertensive patients in the working area of the public health. Behavior formation begins with the smallest social group that starts with the family. Achieving a healthy family behavior must be started from each family. Because a person's behavior or a healthy community can be influenced by several factors both internal and external, one of which is influenced by the level of knowledge (Hadi, 2015).

This is supported by the results of research conducted by Rendi, Tavip Dwi Wahyuni, Warsono with the title "The Effect of Health Education About Hypertension on Lifestyle Behavior Changes in Hypertensive Clients in Dau District Health Center Malang" in 2017. Samples in this study were 20 people known after behavioral health education is more than 13 people compared with 6 people with good behavior and 1 person who behaves less. While research conducted by Ainal Mardhiah, Aswani Abdullah, Hermansyah with the title "The Effect of Health Education in Increasing Knowledge, Behaviors and Family Skills with Hypertension" In 2016 the samples in this study were 59 respondents, after being given health education there was a change in behavior where good behavior was found 59 people (100\%). The researchers' assumptions are related to the study that the behavior of reducing blood pressure in patients after being given health education, changes in behavior where good behavior by 28 people and bad behavior by 8 people, where patients avoid food restrictions that cause increased BP and do sports, walk casually

With information or health education is very important because it can improve the degree of health by changing a person's behavior from unhealthy to healthy ones. From the results of studies that have been carried out the behavior of hypertensive patients before and after the provision of health education, the results of the analysis using a paired t-test with a significant level $(\alpha=0.05)$ based on the test results obtained p-value $<\alpha(0,000<0.005)$ so it can be concluded that there is an effect of the provision of health education on the behavior of reducing blood pressure in hypertensive patients in 


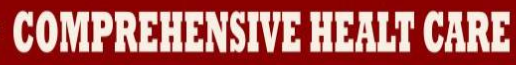

the Bonto Bangun Health Center Work Area. This indicates that the provision of health education will improve a person's behavior in intervening in the disease by controlling and preventing an increase in blood pressure that exceeds normal limits.

This research was previously conducted by Rendi, Tavid Dwi Wahyuni, Warsono with the title "The Effect of Health Education About Hypertension Against Changes in Behavior of Lifestyle Clients in Malang Health Center in 2017". With the results of statistical tests indicate there is an influence of health education about hypertension on the increase in lifestyle behavior with $\mathrm{p}$-value $=0.001<\alpha 0.005$. While research conducted by Ainal Mardiah, Aswani Abdullah, Hermansyah with the title "The Effect of Health Education in Improving Knowledge, Attitudes, Behaviors and Family Skills". The results of this study show that there is an influence of health education on increasing knowledge (0,0001), behavior (0,0001), and skills $(0,0001)$. The researchers' assumptions are related to research that the behavior of reducing blood pressure in hypertensive patients before health education there is a change in behavior from bad behavior to good behavior in which hypertensive patients can control their blood pressure by avoiding food that can cause increased blood pressure

\section{CONCLUSIONS}

Based on the results of the study above, it was concluded that there was an effect of providing health education on the behavior of reducing blood pressure in hypertensive patients in the Work Area of the Bonto Bangun Puskesmas, Rilau Ale, Kab, Bulukumba. The results of this study are expected to provide information and can be used as a guide in providing health education or health promotion and improving work programs related to hypertension

\section{REFERENCES}

Agung, A. A., Panggemanan, J., \& Siagian, I. (2016). Hubungan Tingkat Pengetahuan Masyarakat Dengan Tindakan Pencegahan Hipertensi Di Desa Matoboi Kecil Kecamatan Kotamagu Selatan . Jurnal kedokteran keperawatan dan tropis.

Alimul, A. H. (2014). Metode Peneltian Keperawatan Dan Tehnik Analisis Data. Jakarta: Salemba Medika.

Brian, R. S., Rondonuwu, R., \& Onibala, F. (2015). Hunugan beban kerja dengan kejadian hipertensi pada tenaga pengajar di sma negeri 1 amurang kabupaten minahasa selatan. e journal keperawatan.

Efendi, N. (2012). Dasar-Dasar Keperawatan Kesehatan Masyarakat, Ed.2. Jakarta: EGC 1236.

Hadi, C. (2015). Efektifitas Pendidikan Kesehatan Terhadap peningkatan Pengetahuan Keluarga Tentang Hipertensi. Mutiara Medika. 
Herwati, \& Sartika, W. (2013). Terkontrolnya tekanan darah penderita hipertensi berdasarkan pola diet dan kebiasaan olahraga dipadang tahun 2011. Jurnal kesehatan masyarakat.

Hesriantica, D. Z., \& Diana, R. R. (2017). Hubungan pengetahuan dan riwayat hipertensi dengan tindakan pengendalian tekanan darah pada lansia. jurnal berkala epidemiologi.

Ika, D. P., Hannan, M., \& Dea, L. C. (2017). Pengaruh Jalan Pagi Terhadap Perubahan Tekanan darah Pada Lanjut Usia Dengan Hipertensi Di Desa Kalianget Timur Kecamatan Kaliagent kabupaten sumenap. Ners Lentera.

Kholid, A. (2012). Promosi kesehatan dengan pendekatan teori perilaku, media dan aplikasinya. Jakarta: Rajawali pers.

Kumala, M. (2014). Peran Diet Dalam Pencegahan Dan Terapi Hipertensi . Damianus journal of medicine.

Kurniati, D. p., Inayah, G., \& Samaria, K. (2012). Perilaku Berolahraga dalam Upaya Pencegahan Hipertensi Wanita Usia Produktif Di Pancoran Mas Depok Jawa Barat. Arc. Com. Health.

Lasianjayani, T., \& Martini, S. (2014). Hubungan Antara Obesitas Dengan Perilaku Merokok Terhadap Kejadian Hipertensi. Jurnal Berkala Epidemiologi.

Leidi, M. M., Mulyadi, \& Onibala, F. (2017). Hubungan pengetahuan tentang die garam dengan tekanan darah pada lansiadi puskesmas bahu kota manado. e journal keperawatan.

Lisiswan, R., \& Ulia, D. D. (2016). Upaya pencegahan hipertensi.

Mardiah, A., Abdullah, A., \& Hermansyah. (2016). Pendidikan Kesehatan Dalam Peningkatan Pengetahuan,Sikap Dan Keterampilan Keluarga Dengan Hipertensi. Jurnal ilmu keperawatan.

Martono, N. (2010). Metode Penelitian Kuantitatif. Jakarta: Rajawali Pers.

Notoatmodjo, s. (2012). METODELOGI PENELITIAN KESEHATAN. Jakarta: PT RINEKA CIPTA.

Nurrahmi, U. (2015). Stop diabetes, Hipertensi, Kolestrol dan jantung koroner. Yogyakarta: Istana media.

Prihatmono, I. G., \& Puspasari, F. A. (2017). Pendidikan Kesehatan Dalam Pengelolaan Hipertensi Pada Lansia Di Posbindu BokesanNgemplak Sleman Diy. Media IImu Kesehatan.

Purwati, R., Bidjuni, H., \& Babakal, A. (2014). Pengaruh Penyuluhan Kesehatan Terhadap Pengetahuan Perilaku Klien Hipertensi Di Puskesmas Bahu Manado. E-Journal.

Rina, P. S. (2015). Faktor-Faktor Yang Berhubungan Dengan Kejadian Hipertensi Pada Penderita Rawat Inap Di Rumah Sakit Umum Sari Mutiara Medan Tahun 2014. jurnal ilmiah keperawatan.

Runtukahu, R. F., Rompas, S., \& Pondaag, L. (2015). analisis faktor faktor yang berhubungan dengan kepatuhan melaksanaakan diet pada penderita hipertensi di wilayah kerja puskesmas wolang kecamatan langgoan timur. ejournal keperrawatan.

Saam, Z., \& Wahyuni, S. (2013). Psikologi Keperawatan. Jakarta: Rajawali Pers.

Seke, P. A., Bidjuni, H. j., \& Lolong, J. (2016). Hubungan kejadian stress dengan penyakit hipertensi pada lansia di balai penyantunan lanjut usia senjah cerah kacamatan mapanget kota manado. Ejournal keperawatan.

sudarsono, E. k., Aji sasmita, J. F., Handyasto, A. B., Arissaputra, S. s., \& Kuswantiningsih, N. (2017). Peningkatan pengetahun tentang hipertensi guna perbaikan tekanan 
darah pada anak muda di dusun japan,margodadi,sayegan,sleman,Yogyakarta. Jurnal pengabdian pada masyarakat.

Sugiyono. (2012). Metode Penelitian Kuantitatif Kualitatif dan R\&D. Bandung: Alfabeta.

Sujarweni, W. (2014). Metode Penelitian Keperawatan. Yogyakarta: Gava Media.

Sulistyarini, I. (2013). Terapi Relaksasi Untuk Menurunkan Tekananan Darah Dan Meningkatkan Kualitas Hidup Penderita Hipertensi . Jurnal Psikologi.

sumah, D. F. (2015). Efektifitas pendidikan kesehatan terhap kesehatan terhadap penurunan tekanan darah pasien hipertensi di puskesmas kacamatan amahusu ambon. pendidikan kesehatan,tekanan darah sostolik dan diastolik.

Sumantri, H. A. (2011). Metodologi Peneitian Kesehatan. Jakarta: Kencana.

Sutanto. (2010). CEKAL (cegah dan tangkal) Penyakit MODEREN. Yogyakarta: C.V ANDI OFFEST.

Sutanto, Y., \& Alfian, R. (2015). Perbaikan Perilau Dan Tekanana Darah Pasien Hipertensi Di RSUD H.MOCH ANSARI SALAH Banjarmasin serelah Pemberian Leafleat Edukasi Hipertensi Dan Terapinya. Jurbal IImiah Menuntung.

Tribowo, C., \& Elisya, M. P. (2015). Pengatr dasar ilmu keperawatan. Yogyakarta: Nuna medika.

Udjianti, W. J. (2013). Keperawatan Kardiovaskular. Jakarta: Salemba Medika.

Utami, N., \& Wulan, A. S. (2017). Komsumsi pisang ambong sebagai terapi non farmakologi hipertensi. jurnal keperawatan.

Widianingrum, R., \& Dewi, H. (2013). Efektifitas penyuluhan tentang hipertensi pada masyarakat rentang usia 45-60 tahun dibandingkan dengan masyarakat rentang usia 61-75 tahun. Jurnal kedokteran muhammdiyah.

Yulanda, G., \& Lisiwanti, R. (2017). Penata Laksanaan Hipertensi Primer. Majoriti.

Yumono, G. A., Ridwan, M., \& Hanafi, M. (2017). Pengaruh Pendidikan Kesehatan Tentang Hipertensi Terhadap Tingkat Kecemasan Pada Penderita Hipertensi Di Kabupaten Magelang . Jurnal Keperawatan Soedirman.

Zahidah, A. K., Udiyono, A., \& Adi, M. S. (2016). Gambaran Faktor-Faktor Tekanan Darah Pada Asekptor KB Hormonal Di Wilayah Kerja Puskesmas Kedungmundu 2016. E-juurnal Kesehatan Masyarakat. 